\title{
STUDI LITERATUR PENGARUH EKSTRAK DAUN TEMPUYUNG (SONCHUS ARVENSIS) TERHADAP AKTIVITAS XANTIN OKSIDASE UNTUK PENGOBATAN HIPERURISEMIA
}

\author{
${ }^{1}$ Anisa Adelia \\ Program Pendidikan Dokter Fakultas Kedokteran Universitas Lampung
}

\begin{abstract}
Effect of Daun Tempuyung (Sonchus arvensis) Extract on Xanthine Oxidase Activity For The Treatment of Hyperuricemia. Uric acid levels exceeding the normal limit value in a person's blood will cause hyperuricemia. This disease is classified as a metabolic disease which is a health problem with a high prevalence in both developed and developing countries. The continuous use of drugs or hypouricemic agents in overcoming the problem of hyperuricemia has caused many side effects, this has resulted in people turning to alternative or traditional medicine by utilizing the extract of the tempuyung leaf plant (Sonchus Arvensis) due to the content of secondary metabolite compounds, namely Flavonoids which have the ability in inhibiting the activity of the xanthine oxidase enzyme which converts xanthine to uric acid. Objective : Find out more about the potential of tempuyung leaves as an anti-hyperuricemia agent. Method: Literature studies from various journals both national and international, where literature studies are carried out by reading, understanding and reviewing literature from various sources used. Result : Tempuyung leaf extract has the ability to inhibit the action of the xanthine oxidase enzyme. Conclusion : Tempuyung (Sonchus Arvensis) leaf extract has potential as an anti-hyperuricemic agent. This is due to the content of secondary metabolite compounds found in tempuyung leaves, namely flavonoids which have the ability to inhibit the work of the xanthine oxidase enzyme in converting xanthine to uric acid so that uric acid in a person's blood can be reduced.
\end{abstract}

Keywords : Hyperuricemia; Sonchus arvensis; Xhantine oxidase;

Abstrak: Pengaruh Ekstrak Daun Tempuyung (Sonchus arvensis) Terhadap Aktivitas Xantin oksidase Untuk Pengobatan Hiperurisemia. Asam urat yang kadarnya melampaui nilai batas normal dalam darah seseorang akan mengakibatkan hiperurisemia. Penyakit ini tergolong kedalam penyakit metabolik yang merupakan masalah kesehatan dengan prevalensi cukup tinggi baik di Negara maju ataupun Negara berkembang. Penggunaan obat-obatan atau agen hipourisemia secara terus menerus dalam mengatasi masalah hiperurisemia menimbulkan banyak efek samping, hal tersebut mengakibatkan masyarakat beralih kepada pengobatan alternatif atau tradisional dengan cara memanfaatkan esktrak tanaman daun tempuyung (Sonchus Arvensis) dikarenakan kandungan senyawa metabolit sekundernya yaitu Flavonoid yang memiliki kemampuan dalam menghambat aktivitas enzim xantin oksidase yang mengkonversi xantin menjadi asam urat. Tujuan : Mengetahui lebih lanjut mengenai potensi daun tempuyung sebagai agen anti hiperurisemia. Metode : Studi literatur dari berbagai jurnal baik nasional ataupun internasional, dimana studi literatur dilakukan dengan cara membaca, memahami dan mereview literatur dari berbagai macam sumber yang digunakan. Hasil : Ekstrak daun tempuyung memiliki kemampuan dalam menghambat kerja enzim xantin oksidase. Kesimpulan : Ekstrak daun tempuyung (Sonchus Arvensis) memiliki potensi sebagai agen anti hiperurisemia. Hal tersebut dikarenakan kandungan senyawa metabolit sekunder yang terdapat pada daun 
tempuyung yaitu Flavonoid yang memiliki kemampuan dalam menghambat kerja enzim xantin oksidase dalam mengkonversi xantin menjadi asam urat sehingga asam urat dalam darah seseorang dapat ditekan kadarnya.

Kata Kunci : Hiperurisemia; Sonchus arvensis; Xantin oksidase;

\section{PENDAHULUAN}

Prevalensi hiperurisemia telah mengalami peningkatan diseluruh dunia baik negara maju ataupun negara berkembang. Hiperurisemia merupakan suatu kondisi dimana kadar asam urat didalam darah seseorang melampaui batas nilai normalnya (3-5 mg/dL), yang mana pada laki-laki dikatakan hiperurisemia apabila kadar asam uratnya > $7 \mathrm{mg} / \mathrm{dL}$ dan pada perempuan apabila kadarnya $>6 \mathrm{mg} / \mathrm{dL}$ atau kadar normal dari gout ketika $<6$ $\mathrm{mg} / \mathrm{dL}$. Hiperurisemia terjadi akibat sintesis yang berlebihan dari asam urat dan kegagalan ginjal dalam mengeliminasi asam urat, atau kombinasi faktor-faktor tersebut (Muhtadi, 2015). Hiperurisemia apabila dibiarkan maka akan memicu beberapa kelainan klinis lainnya berupa kelainan ginjal, kardiovaskuler dan gout (Cendrianti, 2014).

Risiko yang ditimbulkan dari gout itu sendiri dapat berupa manifestasi klinis seperti arthritis gout, nefropati gout, batu urat, serta tofus atau akumulasi kristal di jaringan yang merusak tulang (Dianati, 2014). Gout merupakan produk akhir dari degradasi purin, purin yang mengalami peningkatan dapat berasal dari produksi yang berlebih atau dapat juga dari produksi yang kurang matang (Fariz, 2018). Purin dapat berasal dari makanan yang kita konsumsi, konversi asam nukleat pada jaringan menjadi purin nukleotida dan sintesis de novo dari basis purin (Dipiro, 2012). Biasanya peningkatan kadar asam urat dalam darah dipengaruhi oleh keseimbangan antara dietary intake serta sintesis dan ekskresi dari kristal urat itu sendiri (Muhtadi, 2015).

Pada proses pembentukan asam urat, xantin oksidase memiliki peranan yang sangat penting yaitu dalam mengubah xantin menjadi hipoxantin kemudian menjadi asam urat. Kadar purin yang meningkat tersebut lah yang mempengaruhi kerja dari enzim xantin dalam membentuk asam urat (Azmi, 2010). Berdasarkan hasil penelitian yang telah dilakukan oleh Health Proffesionals Follow-up Studies (HPFS) dan juga The Third National Health and Nutrition Examination Survey III (NHANES) menyatakan bahwa terjadinya peningkatan kasus hiperurisemia berkaitan dengan lifestyle (Choi, 2010). Pasien yang menderita penyakit Gout ini akan merasakan rasa sakit serta bengkak dan panas pada daerah persendiannya (Fua dan Yee, 2016).

Gout merupakan salah satu penyakit yang mempengaruhi lebih dari $1 \%$ orang dewasa di dunia dan umumnya lebih banyak menyerang lakilaki (Ar'ev, 2012). Hal ini dikarenakan pada laki-laki tidak memiliki hormon esterogen, sedangkan pada perempuan terdapat hormone esterogen yang dapat membantu pembuangan asam urat melalui urine (Angelina 2014). Tingkat kejadian hiperurisemia di Indonesia pada usia kurang dari 34 tahun yaitu berkisar $32 \%$ dan diatas 34 tahun berkisar 68\% (Pratiwi, 2013). Penyakit asam urat dperkirakan terjadi pada 840 orang dari setiap 100.000 orang. Menurut World Health Organization (WHO) tahun 2013, sebesar 81\% penderita asam urat di Indonesia hanya $24 \%$ saja yang pergi ke dokter, sedangkan sisanya yaitu kurang lebih $71 \%$ cenderung langsung mengkonsumsi obat-obatan pereda nyeri yang dijual bebas (Jaliana, 2018). Pengobatan dan pecegahan hiperurisemia dapat dilakukan melalui beberapa cara yaitu mengatur pola diet (membatasi asupan makanan yang kaya purin), pengobatan secara medis maupun tradisional. Pengobatan secara medis dapat dilakukan dengan cara 
pemberian obat-obatan urikosurik yang bekerja dengan cara meningkatkan kliren ginjal dengan menghambat reabsorbsi asam urat pada tubulus, selain itu dapat juga dengan cara menghambat sintesis asam urat melalui pemberian obat alopurinol atau dengan menghambat masuknya leukosit ke dalam sendi yang terkena deposit asam urat dengan pemberian obat kolkisin. Namun penggunaan obat-obatan tersebut secara berlebihan dapat menimbulkan efek samping (Susanti, 2011). Oleh karena itu dicarilah alternatif lain berupa pengobatan secara tradisional melalui tanaman yang memiliki peran terhadap aktivitas hiperurisemia.

Menurut $\mathrm{WHO}$, pemanfatan
keanekaragaman hayati atau bioprospecting masih sangat besar yaitu mencapai $81 \%$ penduduk di dunia terutama negara yang sedang berkembang masih menggantungkan dirinya pada ekstrak dan bahan bioaktif dari tumbuh-tumbuhan sebagai obat atau memiliki kecenderungan untuk kembali kepada cara-cara pengobatan yang menerapkan konsep black to nature (Chairul, 2013). Penelitian mengenai khasiat tanaman obat yang memiliki aktivitas anti asam urat dengan mekanisme penghambatan enzim xantin oksidase telah banyak dilakukan di beberapa negara seperti Amerika Serikat, India, China, Taiwan bahkan di Indonesia. Daya inhibisi yang telah dilaporkan bervariasi yaitu antara 20\%-80\% (Chang, 2010).

Salah satu tanaman yang secara empiris dipercaya dapat menurunkan kadar asam urat adalah daun tempuyung (Sonchus arvensis) (Djohari, 2015). Penelitian melaporkan bahwa ekstrak daun tempuyung dapat menghambat kerja enzim xantin oksidase dalam mengubah xantin menjadi asam urat sebab tempuyung memiliki kandungan Flavonoid Apigenin 7-O-Glukosida (Izzah, 2010). Tidak hanya itu, daun tumbuhan ini juga memiliki kandungan ion-ion mineral antara lain silika, kalium, magnesium, natrium dan beberapa flavonoid (kaempferol, luteolin-7-Oglukosida, dan apigenin-7-O-glukosida), kumarin (skepoletin), taraksterol, inositol, serta asam fenolat (sinamat, kumarat, dan vanilat) (Cendrianti, 2014).

Berdasarkan latar belakang tersebut, penulis bermaksud melakukan tinjauan literature yang bertujuan untuk mengetahui pengaruh ekstrak daun tempuyung terhadap aktivitas enzim xantin oksidase untuk pengobatan hiperurisemia.

\section{METODE}

Metode yang digunakan oleh penulis adalah studi literatur dari berbagai jurnal baik nasional ataupun internasional, dimana studi literatur dilakukan dengan cara membaca, memahami dan mereview literatur dari berbagai macam sumber yang digunakan. Metode ini digunakan dengan tujuan untuk menyajikan, menambah pengetahuan, dan pemahaman mengenai topik yang dibahas dengan meringkas materi dari sumber jurnal yang telah diterbitkan serta memberikan informasi berupa fakta atau analisis baru dari tinjauan literatur yang relevan kemudian membandngkan hasil tersebut dalam artikel.

\section{HASIL}

Dari berbagai sumber yang didapat serta dari beberapa penelitian terkait yang telah dilakukan diperoleh data sebagai berikut : 
Tabel 1. Uji fitokimia serbuk dan ekstrak tempuyung

\begin{tabular}{ccc}
\hline $\begin{array}{c}\text { Golongan } \\
\text { senyawa }\end{array}$ & $\begin{array}{c}\text { Hasil uji } \\
\text { serbuk }\end{array}$ & $\begin{array}{c}\text { Hasil uji } \\
\text { ekstrak }\end{array}$ \\
\hline Flavonoid & + & ++ \\
Alkaloid & - & - \\
Tanin & + & + \\
Saponin & - & - \\
Steroid & - & - \\
Triterpenoid & - & - \\
\hline Keterangan: (-): tidak terdeteksi; (+): terdeteksi \\
Sumber: Susanti, Anggi (2011)
\end{tabular}

Berdasarkan penelitian yang dialakukan oleh Anggi Susanti (2011) yaitu bahwa senyawa metabolit sekunder dalam ekstrak daun tempuyung dapat diketahui melalui uji fitokimia. Uji yang dilakukan meliputi uji flavonoid, alkaloid, tanin, saponin, steroid, dan triterpenoid. Uji pendahuluan ini dilakukan untuk mengetahui ada tidaknya flavonoid di dalam ekstrak tersebut yang kemungkinan berperan dalam menginhibisi xantin oksidase. Uji fitokimia dilakukan terhadap serbuk dan ekstrak kasar tempuyung. Hasil uji fitokimia serbuk dan ekstrak (Tabel 1) menunjukkan bahwa keduanya mengandung flavonoid dan tanin. metabolit sekunder flavonoid inilah yang diduga dapat menghambat aktivitas xantin oksidase. Sementara kandungan tanin pada ekstrak dan simplisia diperkirakan sama dilihat dari warnanya yang hampir sama.

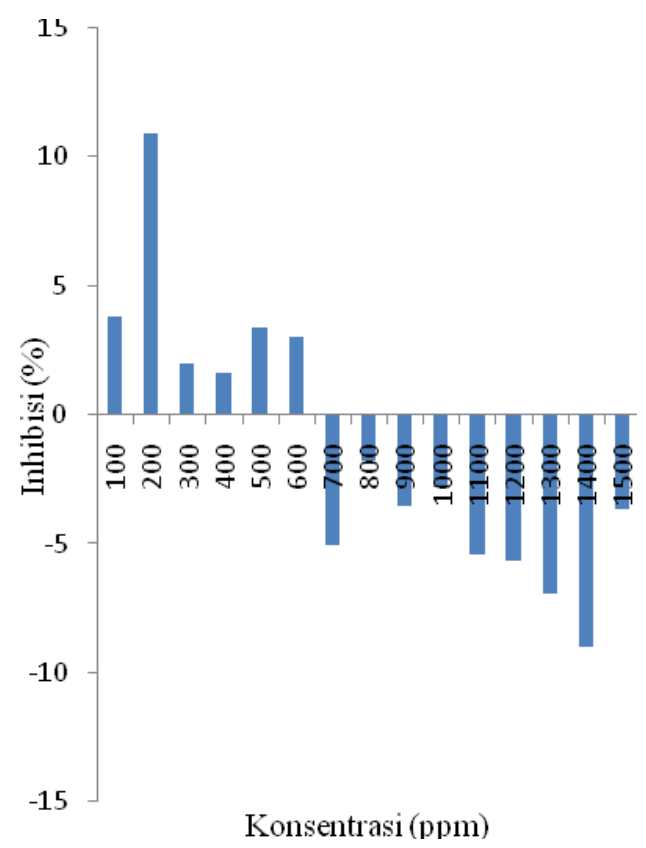

Gambar 1 Inhibisi ekstrak tempuyung terhadap enzim xantin oksidase dalam berbagai konsentrasi.

Sumber: Susanti, Anggi (2011) 
Berdasarkan penelitian terkait bahwa ekstrak kasar tempuyung dapat menghambat aktivitas enzim xantin oksidase mulai dari konsentrasi 100 ppm sampai 600 ppm dengan daya hambat paling besar pada konsentrasi 200 ppm, yaitu sebesar 10.86\%. Namun, pada konsentrasi 700 ppm sampai 1500 ppm ekstrak tersebut

\section{PEMBAHASAN}

Hiperurisemia adalah faktor
terpenting yang berperan
perkembangan Meningkatnya risiko hiperurisemia juga dikaitkan dengan beberapa penyakit penyerta seperti hipertensi, hiperlipidemia, diabetes, penyakit jantung serta obesitas (Cendrianti, 2014). Gout merupakan penyakit progresif akibat penumpukan atau deposisi Kristal monosodium urat (MSU) di sendi, ginjal, dan jaringan ikat lainnya sebagai akibat dari hiperurisemia yang berlangsung kronik. Tanpa penanganan yang efektif kondisi ini dapat berkembang menjadi gout kronis, terbentuknya tofus, dan bahkan dapat mengakibatkan gangguan fungsi ginjal berat, serta penurunan kualitas hidup (Alwi, 2018). Peningkatan kadar asam urat dalam darah, selain dapat menyebabkan gout, menurut suatu penelitian juga merupakan salah satu prediktor kuat terhadap kematian karena dapat mengakibatkan terjadinya kerusakan kardiovaskuler (Jaliana, 2018).

Pencegahan terhadap peningkatan kadar asam urat di dalam darah perlu dilakukan guna menghambat berkembangnya penyakit lain. Pencegahan tersebut dapat dilakukan baik dengan cara medis ataupun non medis. Cara medis yang telah lazim digunakan yaitu dengan cara memberikan obat-obatan atau agen hipourisemia yang mana obat tersebut malah menjadi aktivator. Hal ini disebabkan oleh karena ekstrak yang diujikan masih kasar, sehingga semakin pekat ekstrak, semakin banyak pula senyawa lain yang ikut terekstraksi oleh etanol yang diduga memiliki fungsi bukan hanya untuk menginhibisi (Susanti, 2011).

memiliki 2 mekanisme kerja yaitu urikostatik dan urikosurik. Urikostatik dengan cara bekerja langsung pada enzim yang berperan meningkatkan kadar asam urat yaitu xantin oksidase, sedangkan urikosurik yaitu bekerja dengan cara meningkatkan ekskresi dari asam urat itu sendiri (Cendrianti, 2014). Xantin oksidase merupakan suatu kompleks enzim yang terdiri dari molekul- molekul protein yang mana tiap molekulnya tersusun atas $2 \mathrm{~mol}$ FAD, 2 mol atom Mo dan $8 \mathrm{~mol}$ atom Fe. Enzim xantin oksidase di dalam tubuh terdapat pada hati dan otot. Satu unit xantin oksidase dapat mengkonversi satu $\mu \mathrm{mol}$ substrat (xantin) menjadi asam urat tiap satu menit pada $\mathrm{pH}$ optimum $(\mathrm{pH} 7.5)$ dan suhu optimum $\left(25^{\circ} \mathrm{C}\right)$ (Susanti, 2011).

Salah satu tanaman yang dapat digunakan sebagai antihiperurisemia adalah daun tempuyung, hal ini telah banyak dibuktikan oleh penelitian yang menyebutkan bahwa pada tanaman tersebut terdapat agen atau zat yang menghambat kerja enzim xantin oksidase dalam meningkatkan kadar asam urat dalam darah. Senyawa yang terkandung dalam daun tempuyung yang diduga memiliki aktivitas anti hiperurisemia yaitu flavonoid. Penelitian secara in vitro telah banyak memberikan bukti yang jelas, namun untuk secara in vivo masih dalam proses penelitian lebih lanjut. 

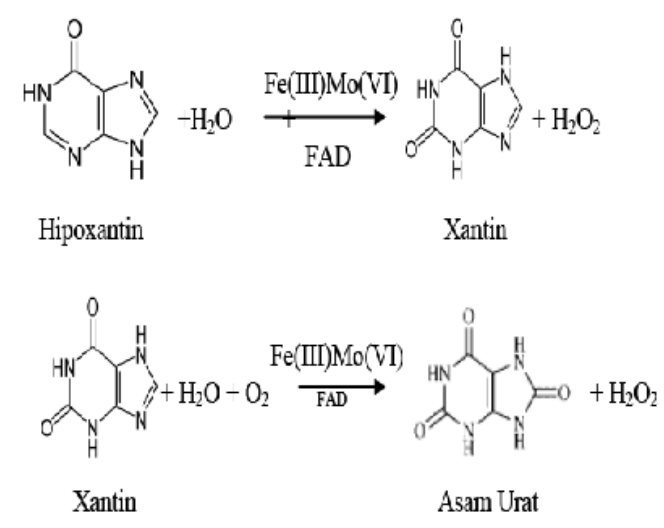

\section{Gambar 2. Skema reaksi xantin oksidase yang mengkonversi hipoxantin menjadi xantin kemudian asam urat \\ Sumber: Cendrianti, Ferani, dkk (2014)}

Penelitian yang dilakukan oleh Ferani Cendrianti dkk (2014) telah membuktikan bahwa ekstrak nheksana, etil asetat dan etanol $70 \%$ daun tempuyung dapat menurunkan kadar asam urat pada mencit putih jantan yang hiperurisemia. Pada penelitian tersebut dituliskan bahwa aktivitas dari ekstrak etanol dan etil asetat tidak lebih besar jika dibandingkan dengan aktivitas dari alopurinol, hal ini terjadi kemungkinan karena konsentrasi senyawa yang memiliki potensi sebagai agen anti hiperurisemia hanya sedikit atau dapat juga karena kandungan senyawa flavonoid dalam daun tempuyung tersebut dalam bentuk flavonoid glikosida yang mana aktivitas penghambatannya lebih kecil jika dibandingan dengan senyawa induknya yaitu apigenin dan luteolin (Cendrianti, 2014).

Senyawa flavonoid yang telah kita ketahui dapat menghambat xantin oksidase dan bersifat menangkap radikal bebas superoksida inilah yang mampu menurunkan kadar asam urat. Namun, jenis-jenis flavonoid seperti apigenin, luteolin, kuersetin dan kaemferol mempunyai potensi cukup baik untuk menginhibisi aktivitas enzim xantin oksidase, sedangkan turunan flavonoid seperti 7- glukosilapigenin memiliki inhibisi lebih rendah dibandingkan flavonoid aslinya, yaitu apigenin (Cendrianti, 2014). Kandungan flavonoid pada ekstrak etanol daun tempuyung yaitu $5,7,3^{\prime}, 4^{\prime}$-tetrahidroksi flavon (luteolin), 5,7, $4^{\prime}$-trihidroksi flavon (apigenin), luteolin 7-O-glukosida, dan apigenin 7-O-glukosida. Flavonoid luteolin dapat menghambat xantin oksidase dengan nilai IC50 sebesar 0,96 $\mu \mathrm{M}$ dan $0,55 \mu \mathrm{M}$, sedangkan apigenin memiliki IC50 sebesar 29,1 $4 \mathrm{M}$ dan 0,70 $\mu$ M (Muhtadi, 2012).

Selain itu, penelitian yang dilakukan oleh wardani (2008) juga telah membuktikan bahwa ekstrak daun tempuyung dan meniran dapat menurunkan kadar asam urat dengan cara menghambat kerja enzim xantin oksidase menjadi xantin. Penelitian yang dilakukan oleh Izzah (2010) membuktikan bahwa gabungan dari ekstrak sidaguri, seledri dan tempuyung berpotensi sebagai anti hiperurisemia melalui penghambatan enzim xantin oksidase secara in vitro dengan persen inhibisi sebesar $88,68 \%$ dan penelitiannya itu sekaligus mengukuhkan gabungan ekstrak tersebut dengan dosis $2640 \mathrm{mg} / 300 \mathrm{~g}$ BB dapat menurunkan konsentrasi asam urat dalam darah tikus sebesar 59,45\% yang melebihi kontrol positif (alopurinol) sebesar $56,86 \%$. Hasil penelitian ini didukung oleh penelitian lain juga yang menyatakan bahwa Flavonoid tempuyung juga berpotensi sebagai komponen antiinflamasi dan antihiperurisemia (Susanti, 2011).

Berdasarkan penelitian yang dilakukan oleh Muhtadi dkk (2015) bahwa ekstrak daun tempuyung dengan 
dosis $200 \mathrm{mg} / \mathrm{kgBB}$ dapat memberikan daya hambat terhadap enzim xantin oksidase sebesar $70,30 \%$ kurang lebih $3,70 \%$ pada mencit yang gout. Penelitian lain juga dilakukan oleh Hendriani (2016) yang mana pada penelitian tersebut menyebutkan bahwa ekstrak etil-asetat pada tanaman Sonchus Arvensis menunjukkan aktivitas penghambatan terhadap enzim xantin oksidase paling baik pada konsentrasi $200 \mu \mathrm{g} / \mathrm{mL}$, sedangkan dengan ekstrak etanol menunjukkan aktivitas penghambatan terhadap enzim xanthine oxidase dengan IC50 sebesar $23,64 \mu \mathrm{g} / \mathrm{mL}$. Namun penelitian yang dilakukan Koting (2013) didapatkan hasil bahwa fraksi etil-asetat pada tanaman Sonchus arvensis menunjukkan efek yang paling besar dalam menurunkan kadar asam urat yaitu pada dosis $2,0 \mathrm{~g} / \mathrm{kgBB}$.

Senyawa flavonoid yang telah terbukti dari berbagai penelitian dapat menghambat enzim xantin oksidase disebabkan oleh karena adanya gugus hidroksil pada atom C-5 atau C-7 serta adanya ikatan rangkap antara C-2 dan $\mathrm{C}-3$, hal inilah yang memungkinkan terjadinya reaksi adisi (oksidase oleh xantin oksidase) sehingga cincin B menjadi co-planar terhadap cincin A dan C. Kemampuan flavonoid dalam menghambat aktivitas xantin oksidase yaitu melalui mekanisme inhibisi kompetitif dan interaksi dengan enzim pada gugus samping (Muhtadi, 2012).

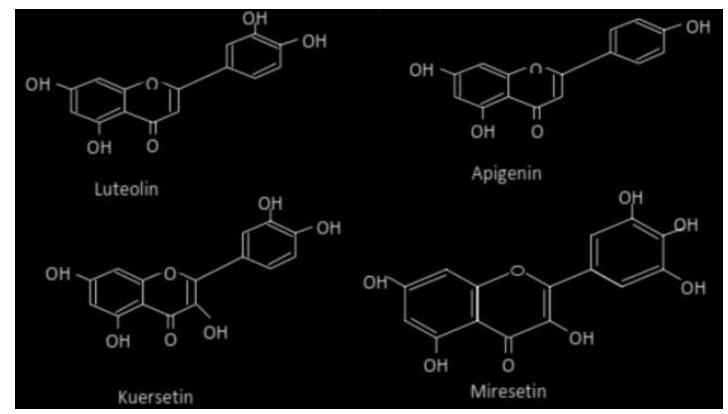

Gambar 3. Struktur Flavonoid Flavon (Apigenin, Luteolin) dan Flavonol (Kuersetin, Miresetin)

Sumber: Muhtadi (2012)

\section{SIMPULAN}

Ekstrak daun tempuyung (Sonchus Arvensis) memiliki potensi sebagai agen anti hiperurisemia. Hal tersebut dikarenakan kandungan senyawa metabolit sekunder yang terdapat pada daun tempuyung yaitu Flavonoid yang memiliki kemampuan dalam menghambat kerja enzim xantin oksidase dalam mengkonversi xantin menjadi asam urat sehingga asam urat dalam darah seseorang dapat ditekan kadarnya.

\section{SARAN}

Perlu dilakukan penelitian lebih lanjut mengenai kemampuan aktivitas flavonoid daun tempuyung secara in vivo.

\section{DAFTAR PUSTAKA}

Alwi, Idrus. (2018). Pedoman Diagnosis dan Pengelolaan Gout. Jakarta : Perhimpunan Reumatologi Indonesia.

Angelina, F., DK, K., \& Wirawanni, Y. (2014). Perbedaan Pengaruh Asupan Kacang Tanah (Arachis Hypogaea) Rebus Dan Panggang Terhadap Kadar Asam Urat Dalam Darah Pada Wanita Dislipidemia. Journal of Nutrition College. Vol. 3(2) : 278-284.

Ar'ev AL., Kunitskaia NA., \& Kozina LS. (2012). Gout and Hyperuricemia Today : Prevalence, Risk Factors, Features In The Elderly. NCBI. Vol. 25(3). 
Azmi, Ulul. (2010). Efek Ekstrak Etanol Daging Buah Mahkota Dewa Terhadap Penurunan Kadar Asam Urat Pada Mencit Putih Jantan Yang Diinduksi Potassium Oxonate. Naskah Publikasi Skripsi. Universitas Muhammadiyah Surakarta (UMS).

Cendrianti, Ferani., Muslichah, Siti., \& Ulfa, Evi Umayah. (2014). Uji Aktivitas Antihiperurisemia Ekstrak n-Heksana, Etil Asetat, dan Etanol 70\% Daun Tempuyung (Sonchus arvensis L.) pada Mencit Jantan Hiperurisemia. e-Journal Pustaka Kesehatan. Farmasi Universitas Jember. Vol. 2(2) : 205-209.

Chairul, Sofnie M., Sumarny, Ros., \& Chairul. (2013). Aktivitas Anti Oksidan Ekstrak Air Daun Tempuyung (Sonchus Arvensis. L) Secara In Vitro. Majalah Farmasi Indonesia. Vol. 14(4) : 208-215.

Chang, ST., \& Tung, YT. (2010). Inhibition of Xanthine oxidase by Acacia Confuse Extract and Their Phytochemicals. Journal Agric Food Chem. Vol. 58 : 781-786.

Choi, HK. (2010). A Prescription for Lifestyle Change in Patients with Hyperuricemia and Gout. Current Opinion Of Rheumatology. Vol. 22(2) : 165-178.

Dianati, NA. (2015). Gout and Hyperuricemia. Journal Majority. Vol. 4(3) : 82-89.

Dipiro, Joseph T., Talbert, Robert L. (2012). The Seventh Edition of The Benchmark Evidence-Based Pharmacotherapy. McGraw Hill Companies Inc. USA.

Djohari, Meiriza., \& Rovi, Paramitha. (2015). Efektivitas Rebusan Daun Salam ( Syzygium Polyanthum) Terhadap
Penurunan Kadar Asam Urat Dalam Darah Mencit Putih Jantan. Jurnal Pharmacy. Vol. 12(2).

Fariz, Abshar., Fauzi, Rakhmat., \& Rizki, Muhammad Ikhwan. (2018). Review : Tanaman Obat yang Berefek Sebagai Antigout. Jurnal Pharmascience. Vol. 5(1) : 2231.

Fua, TP., \& Yee, HD. (2016). Acute Hip Pain-A Forgotten Cause. Journal International of Clinical Medicine. Vol. 7 : 177-181.

Hendriani, R., Elin, YS., \& Kusnandar A. (2016). In Vitro Evaluation of Xanthine Oxidase Inhibitory Activity Of Selected Medicinal Plants. International Journal of Pharmaceutical and Clinical Research. Vol. 8(4) : 235-238.

Izzah. (2010). Ekstrak Seledri (Apium Graveolens), Sidaguri (Sida Rhombifolia), dan Tempuyung (Sonchus Arvensis L) Sebagai Anti Hiperurisemia In Vitro dan In Vivo. Naskah Publikasi Skripsi. Fakultas Matematika dan IImu Pengetahuan Alam Institut Pertanian Bogor.

Jaliana., La Ode, Suhadi., \& Sety, Muhammad. (2018). FaktorFaktor yang Berhubungan dengan Kejadian Asam Urat pada Usia 20-44 tahun di RSUD Bahteramas Provinsi Sulawesi Tenggara 2017. Jurnal IImiah Mahasiswa Kesehatan Masyarakat (JIMKESMAS). Vol. 3(2) : 2-11

Koting, I. S. B. (2013). Pengaruh Fraksi Etil Asetat Ekstrak Etanol Daun Tempuyung (Sonchus Arvensis $L$ ) Terhadap Kadar Asam Urat Dalam Darah Tikus Putih Jantan Galur Wistar Hiperurisemia. Universitas Katolik Widya Mandala Surabaya. 
Mutadi, dkk. (2015). Uji Penghambatan Xanthine Oxidase Oleh Ekstrak Daun Tempuyung (Sonchus Arvensis) Pada Mencit Hiperurisemia. University Research Colloquium. 82-88.

Muhtadi., Retnani, Idi., \& Wahyuningtiyas, Nurcahyanti. (2012). Penghambatan Xhantine Oxidase Oleh Kombinasi Ekstrak Tempuyung (Sonchus Arvensis L) dan Salam (Syzygium Polyanthum) Pada Mencit Hiperurisemia. Fakultas Farmasi Universitas Muhammadiyah Surakarta. Vol. 4(1) : 17-21.

Pratiwi, V.F. (2013). Gambaran Kejadian Asam Urat (Gout) Berdasarkan Kegemukan dan Konsumsi Makanan. Naskah Publikasi Skripsi. Universitas Jember.

Susanti, Anggi. (2011). Pengaruh Ekstrak Tempuyung (Sonchus Arvensis L) Terhadap Aktivitas Xantin Oksidase Secara In Vitro Sebagai Dasar Uji Kinetika. Naskah Publikasi Skripsi. Departemen Kimia Fakultas Matematika dan Ilmu Pengetahuan Alam Institut Pertanian Bogor. 